\title{
Beautiful Nightmares: Low Self-Esteem Causes and Effects to Lara and Ayunindya's Life
}

\author{
Jessica Azalea Hendrike \\ English for Creative Industry, Faculty of Languages and Literature, Petra Christian University, \\ Siwalankerto 121-131, Surabaya 60236, East Java, INDONESIA \\ Email: m11415048@john.petra.ac.id
}

\begin{abstract}
My screenplay Beautiful Nightmares is the story of Lara, a singer and Ayunindya, the assistant manager who both struggling with their self-esteem. Using crime as the genre of my story and Film Noir as the subgenre, I look into the worst nightmare of two persons with low self-esteem can bring to someone else. The main idea of my creative writing focuses on the causes and effects of low self-esteem, I also deal with the roles of family and friends in influencing someone value of him or herself. However I believe low self-esteem can cause a big nuisance, especially when it comes to anxiety, obsession, violence and ended up with criminal behavior. To help me creating this screenplay, I use the theory of The Looking Glass Self by Charles Horton Cooley, theory of Self-Esteem and Adolescent by Morris Rosenberg, the theory of possession by L. Firestone, and Rosenbaum and DeCharms' theory of criminal behavior on someone with a low self-esteem. Later in the story it reveals how Lara and Ayunindya's self-esteem are influenced by their family and friends. Furthermore, they ended up committing murder.
\end{abstract}

Keyword: Low Self-Esteem, Possession, Criminal behavior.

\section{INTRODUCTION}

\section{Background of Creative Work}

How we see ourselves is the most important thing that will affect our life in everything, especially someone's success (Cherry, 2019). A lot of people are not exactly aware with this and without them realizing, self-esteem is becoming one of the biggest monsters that they could ever have. Self-esteem is the positive or negative evaluations of the self, as in how we feel about ourselves (Smith and Mackie, 2007). Self-esteem reflects an individual's overall subjective emotional evaluation of his or her own worth. There are a lot of factors that can influence selfesteem, for example genetics, personality, life experiences, age, health, thoughts, social circumstances, the reactions of the others and comparing the self to others (Positive Psychology Program, 2018). The level of self-esteem and confidence can be gained from all experiences and interpersonal relationship people have had in their life (Galli and Humphrey, 2000).

In this creative thesis I would like to focus on low self-esteem. Low self-esteem is when a person does not think positively about him or herself. For example, they will think that they are ugly and fat, they are worthless, pathetic, and a complete failure. All of that negative energy can lead them to dissatisfaction (Galli and Humphrey, 2000). Also, they will have less happiness and enjoyment in life, have less meaningful life, less confidence, more stress and have an anxiety to many things and a tendency to hurt themselves.

According to a survey, low self-esteem is mostly happen to girls rather than boys. Self-esteem continues to decline during adolescence particularly for girls (McLeod, Low Self Esteem in Teenagers, 2012). In Indonesia, it is proven by Dove Girl Beauty Confidence Report, $54 \%$ of young women are having a low self-esteem (Cahyu, 2018). They also claim over half of teenage girls around the world have no confidence or high self-esteem about their body. Also, 
a recent study in United Kingdom, reveals that a massive 70\% of girls feel that they are not meeting expectations that they believe are placed on them by their surroundings, and do not feel "good enough". Overall, the girls who are unhappy about their looks rose to $33 \%$ in 2013, from $29 \%$ in 2012 and $26 \%$ in 2011. At ages 14 to 16, 51\% of girls are unhappy with their appearance, and even after that age, 52\% are still unhappy (Meikle, 2013).

According to Misetich and Delis-Abrams in their studies, low self-esteem is linked to violence, school dropout rates, teenage pregnancy, suicide, and low academic achievement (Ackerman, 2018). Based on the research in Developmental Psychology, the effects of having low selfesteem are anxiety, poor health, criminal convictions, low economic prospect and depression (Trzesniewski, Moffitt, Poulton, Donnellan, W.Robins, \& Caspi, 2006). Depression and criminal convictions are the most common effect of low self-esteem.

The reason why I use screenplay as the form of my creative work is to convey the messages that I want to show to the audiences. It has been proven that movies are getting better in engaging with people nowadays. People are more likely to watch movies more rather than to read books. The quality of Indonesian movies nowadays is also getting better. These days the number of movie audience is increasing. The increasing number is quite high compare to in 2015 which is only 16 million; in 2017 the number of people who are going to cinema is reaching 42.7 million people (Setiawan, 2018).

In film industry there is one genre that never dies, which is crime. This is one of the reasons why I choose crime as the genre of my creative works. Another reason is because crime genre has the most interesting twist than any other genre. The discovery of what was hidden, of the revelation of truth, takes place in the audience. This is exactly like I want to convey in my story. In crime genre, not only do they always find the culprit, they also reveal the reason behind their action. I choose film noir-subgenre because this is the most suitable for my story. I use Film Noir as the subgenre because it also consists of drama. The film noir genre includes stylish Hollywood crime dramas, often with a twisted dark wit (Naremore, 2008; Ballinger \& Graydon, 2007).

\section{Statement of the Problem}

This creative work will try to find out the cause of low self-esteem and how the negative effects come up from low self-esteem.

To be more specific, I want to reveal about:

a. Why Lara and Ayunindya have low self-esteem.

b. How negative effects come up from Lara and Ayunindya's low self-esteem.

\section{Purpose of the Creative Works}

In this work I want to prove that the causes of low self-esteem are ignorance from someone's surroundings especially family and lover. Also the negative effects come up from low self-esteem are depression, anxiety, self-harming and it will lead to violence to themselves and their surroundings. I also want to show that:

a. Lara and Ayunindya have a low self-esteem because no matter how hard they tried, no one will never look at them and listen to them.

b. Lara and Ayu's low self-esteem cause anxiety, insecurity, self-harming, and violence towards Kian. 


\section{Significance of the Work}

By reading my screenplay the reader will be aware about what is self-esteem, especially low self-esteem. Many movies use this topic as their side topic, they do not explore more about self-esteem topic. Here I want to make this topic as the main topic and explore more about it. The movies that talk about self-esteem are mostly using a drama as their genre. However I use crime genre to discuss about low self-esteem. Even though in film noir they combine crime and drama, I focus more to the crime genre. Also I use the first person point of view of the protagonist and narration. Hopefully later the readers will be more encouraging towards others and have more sympathy with their surroundings. I hope by talking about this issue, more people will understand about those who suffer from low self-esteem and can help them to be better.

\section{Methodology}

In making this work, I use the secondary data. I already did the library research and look for the theory from books to collect the data. I found some definition about self-esteem and what might cause having low self-esteem. I also use movies as my reference like NCIS (Bellisario \& McGill, 2003), Criminal Minds (Davis, 2005) and Sherlock Holmes (Ritchie, 2009). From these movies I collect the data about the psychology of the suspect, like the reason why the suspect kill the victim, or what is the reason behind the game that the suspect creates. I also watched The Great Gatsby (Fitzgerald, Luhrmann, \& Pearce, 2013) to get some ideas about low self-esteem and its effect. I also watch some movies that used self-esteem as their topic to see if there are any movies about low self-esteem and how they portray people with this kind of self-esteem. Besides doing library research, I also use internet as my source. I read about self esteem, low and high self esteem, about self development, and about the crime genre, and also the theories of self-esteem.

\section{OUTLINE OF THE CREATIVE WORK}

\section{Theme}

The problem that my screenplay wants to talk about is about low self-esteem. As for the theme, my screenplay is trying to reveal that having a low self-esteem can destroy someone's life. Many think having a low self-esteem is a common thing and nothing should be worry about. Lara, the main character of my story is a singer and for other people, Lara's life is perfect. But inside, Lara hides the pain. She never got the acknowledgement she always wanted from her family back then. She always thinks that she is useless and worthless because her families always look at her as one. Ayunindya on the other hand, is the assistant manager, gained her low self-esteem because of her friends. She has her own revenge towards Kian, the lead male of the story. My screenplay shows how broken Lara and Ayunindya are because of their low selfesteem and what happened to them and also their surroundings because of that.

\section{Pitch}

a. Ayunindya is the new assistant manager of Lara, a singer, who has no one besides her manager who is also her childhood best friend, Kian who suddenly found dead in his house. 
b. Ayunindya, the assistant manager, who is trying to find out why Kian died, finally finds out that actually Lara is the one who killed Kian, but Ayunindya is morally corrupted after she finds out the truth behind Lara's reason to kill Kian.

c. At the end, it reveals that it was all planned by Ayunindya and how she manages to manipulate Lara to kill Kian and play her part.

\section{Synopsis}

Ayunindya is the assistant manager of a singer, Lara. One night, Kian, the manager is found dead in his house. Ayunindya finds out that there is something suspicious about the case. She tries to investigate it by herself according to the clues she found. Lara is trying to stop Ayunindya to talk and try to find out about the case. In her long journey to find the truth, there are times that she always finds a dead end and she cannot move further. She often gets a threat because she keeps on trying to reveal the truth. After a long time of investigation, the clues lead her to Lara as the main suspect of the murdered.

Until one day, she finds out that it is true that Lara killed Kian at that time and played a good acting when she found Kian died in his house. In here Lara talks about her feelings, about her anger and how she got depress just because she was disappointed with him. At the end she tells the police who is the killer. The plot twist here shows the real killer of Kian. Actually, it was both of them who killed Kian that night. All of those problems were just an act and Ayunindya is the brain of it. She tries to manipulate Lara and makes her as her puppet.

\section{Characters}

\section{Main Character:}

a. Lara (21 years old)

Lara is the last child in her family. Being the last child, it does not mean Lara can have privilege to be what she wants to be and having all the attention. Instead, her parents gave almost no attention to her. She always tried to amuse her parents by got the highest score in math test, drew a beautiful picture about the family, picked as the captain of the class, and many more, but still she got no attention from her parents. She feels insecure, and along with the time, she grew as a girl who has no confident in herself. She is an overthinking, hardworking, insecure, and scared to do new things kind of girl.

\section{b. Ayunindya (24 years old)}

Ayunindya was come from a middle class family. Since she was a child, she lived with her mother and her brother. Back then when she was in high school she was bullied by her friends because of a scandal about her and one of the teachers in school. Her first love, Kian, also one of the bullies. She dropped out from school and made her lose her mother trust and also her friends. She is a hotheaded, manipulative, and an introvert who always keeps everything for herself. Because of the grudge she has against Kian, later she plans to get her revenge towards him.

\section{Supporting Character:}

\section{a. Kiandra (24 years old)}

Kiandra is Lara's manager. Kian is arrogant, but dependable man. He took care of Lara and made sure the girl got the acknowledgement from the people. He always thinks that everything he does are right, and no one can tell him what to do and what not to do. He also a selfish man who thinks that he is the best and he can get anything he wants. He is one of those sly guys who can make the girls fall in love with him and he takes the advantages from them.

b. Deborah (45 years old) 
She is the psychiatrist who Ayunindya goes to. She is a calm and generous person. She is also a wise woman and never judges a person by their first meet.

c. Detective Randy (31 years old)

He is the detective who responsible of Kian's murder case. He is smart, strong willing and a sensible person. He has been work as a detective for about 10 years.

\section{d. Julian (24 years old)}

He is Kiandra's friend at college. He is one of the closest friends that Kian has, but Julian has to leave to another country while Kian stays in Jakarta. He does not know that Kian has a close relationship with Lara because Kian hides it.

\section{e. Security (54 years old)}

He is the security in Lara's house. He is a kind and wise old man. He works at Lara's house for more than 4 years.

\section{f. Shop Keeper (43 years old)}

She is a shop keeper in a pharmacy near Lara's lake house.

\section{Conflict}

The conflict in my screenplay is man vs man conflict, but also about self-conflict that is influenced by and influences others. Lara who longed for an appreciation, attention and love got all of it in a form of her best friend, Kian. She adores him and slowly she starts to depend on him entirely. One day Lara heard that Kian will marry someone else. Lara feels betrayed and finally did something out of her mind. So does with Ayunindya who wants to do revenge to Kian. Kian bullied her in high school and it makes her wanted Kian to pay back all the pain she had felt back then.

\section{Setting}

- Place

Jakarta, Indonesia.

Jakarta is the capital city of Indonesia. It is well known as a city with a strong competition and most of the people who live there are individuals.

- Time

The time starts in present, but then moves back to 2 years before that.

\section{CONCLUSION}

By choosing creative work as my final project and to be exact to write a 60 minutes screenplay, I have learn a lot of new things more than just how to write a great screenplay. Exploring the originality of self-esteem, different perspective from a lot of researchers and experts about low self-esteem, and how self-esteem is build and how it turns out make me understand more regarding this topic.

First, my purpose of creating this screenplay is to make people aware about low self-esteem and how it will affect someone's life. In my creative writing Beautiful Nightmares, I make two of the main character have this kind of self-esteem. Lara and Ayunindya both have a low selfesteem, but how it build and how it turns out are a little bit different. Both of them have their own struggles that people do not aware of. In here I want to show that low self-esteem 
sometimes is not visible to the eyes. It can happen to anyone and others will never know what will happen to them.

Second, what I want to highlight from Beautiful Nightmares is the cause of low self-esteem. Low self-esteem can be caused by various factors. In my screenplay, Lara's self-esteem comes from her late family. Her parents and her siblings hate her. It makes her got lack of love from the people around her. The harsh and rude words that they said to her stay on her mind and at the end, she always looks at herself like how her families look at her. She starts to hate herself too. While Ayunindya's low self-esteem caused by her friends and her experiences in high school. She was bullied by her friends in class and almost the entire school. The pressure she got from her friends make her has this kind of self-esteem. She has no confidence and she is too scared to talk to others right after the accident where Kian embarrassed her in front of her friends.

Third, the last thing I want to highlight from this screenplay is the effect of low self-esteem. The effect to Lara is more into she has no confidence with herself and she easily influenced by others word because she always thought that what others said is right and she should follow. Ayunindya on the other hand, is more into an action effect. She's getting angry and wanting revenge. She believes that someone has to be responsible of her feeling. But both of them have the similarity which is becoming violent to release their anger towards someone.

\section{REFERENCE}

Ackerman, C. (2018, May 23). What is Self-Esteem? A Psychologist Explains. Retrieved May 24, 2019, from Positive Psychology Program: https://positivepsychologyprogram.com/self-esteem/

Bellisario, D. P., Bellisario, D., Drewe, A. C. (Producers), Bellisario, D. P., \& McGill, D. (Directors). (2003). NCIS [Motion Picture]. United States of America: CBS Television Distribution.

Berman, B. (Producer), \& Ritchie, G. (Director). (2009). Sherlock Holmes [Motion Picture].

Fisher, L., Knapman, C., Luhrmann, B., Martin, C., Wick, D. (Producers), Fitzgerald, F. S., Luhrmann, B., Pearce, C. (Writers), \& Luhrmann, B. (Director). (2013). The Great Gatsby [Motion Picture]. Australia \& United States of America: Warnes Bros. Pictures.

Gordon, M., Davis, J. (Producers), Davis, J. (Writer), \& Davis, J. (Director). (2005). Criminal Minds [Motion Picture]. United States of America: CBS Television Distribution.

Naremore, J. (2008). More Than Night: Film Noir in Its Contexts. University of California Press.

Setiawan, T. S. (2018, February 28). Jumlah Penonton Bioskop Indonesia Capai 42,7 Juta pada 2017. Kompas.com. 